\title{
Multiparasitism in gills of Metynnis lippincottianus from the environmental protection area of Curiaú river, Eastern Amazon
}

\section{Abthyllane Amaral de Carvalho ${ }^{1}$ Roger Leomar da Silva Ferreira ${ }^{1}$ Priscila Gomes de Araújo $^{1}$ Márcio Charles da Silva Negrão ${ }^{2}$ Marcela Nunes Videira $^{3^{*}}$ (D)}

${ }^{1}$ Laboratório de Morfofisiologia e Sanidade Animal, Programa de Pós-graduação em Ciências Ambientais, Universidade Federal do Amapá (UNIFAP), Macapá, AP, Brasil.

${ }^{2}$ Laboratório de Morfofisiologia de Sanidade Animal, Programa de Pós-graduação em Biodiversidade Tropical, Universidade Federal do Amapá (UNIFAP), Macapá, AP, Brasil.

${ }^{3}$ Laboratório de Morfofisiologia de Sanidade Animal, Programa de Pós-graduação em Ciências Ambientais, Universidade do Estado do Amapá (UEAP), Campus I, 68900-070, Macapá, AP, Brasil. E-mail: marcela.videira@ueap.edu.br. "Corresponding author.

ABSTRACT: The high fish diversity of the Amazon has been the subject of study for several research projects because of the importance of its ecosystems. The Environmental Protection Area of the Curiau River is composed of permanent and temporary lakes within the floodplain forests, favoring a rich diversity of fish species. Pratinha. (Metynnis lippincottianus) is an ornamental fish, widely distributed throughout Brazil and French Guiana. Fish parasites may reflect the environmental quality, as well as the habits of their host. Considering the importance of understanding and contributing to the expansion of studies on fish parasites, the present study aimed to investigate the gills of Metynnis lippincottianus from the Curiaú River basin in the municipality of Macapá (Eastern Amazon). A total of 200 specimens of Metynnis lippincottianus from the Curiau River were examined and $89 \%$ of the analyzed fish were parasitized by metacercariae, Dactylogyridae gen. sp., Piscinoodinium pillulare, Trichodina sp., Henneguya sp., and Myxobolus sp. Despite this high parasitic load, body conditions were not affected. This is the first documented incidence of a species belonging to the Phylum Cnidaria: Myxozoa in Metynnis lippincottianus. Key words: ornamental fish, parasitic fauna, infection.

Multiparasitismo em brânquias de Metynnis lippincottianus da área de proteção ambiental do rio Curiaú, Amazônia Oriental

RESUMO: A alta diversidade ictiológica da Amazônia tem sido fonte de estudo de diversas pesquisas, por esta região amazônica englobar alguns ecossistemas importantes. A Área de Proteção Ambiental do Rio Curiaú é composta por lagos permanentes e temporários dentro das florestas de várzeas, o que favorece em uma rica diversidade de espécies de peixes. Metynnis lippincottianus é um peixe ornamental, amplamente distribuido pelo Brasil e Guiana Francesa. Os parasitos de peixes podem refletir a qualidade ambiental, assim como nos hábitos de seu hospedeiro. Considerando a importância de entender e contribuir para a expansão dos estudos sobre parasitos de peixes, o presente estudo teve como objetivo, investigar as brânquias de Metynnis lippincottianus oriundos da bacia do Rio Curiaú no município de Macapá-AP (Amazônia Oriental). Foram examinados 200 exemplares de Metynnis lippincottianus, oriundos do rio Curiaú, sendo que 89\% dos peixes analisados estavam parasitados por parasitos diversos: Piscinoodinium pillulare, Trichodina sp., Henneguya sp., Myxobolus sp., monogenoide da família Dactylogyridae e metacercárias. Apesar dessa alta carga parasitária, as condições corporais não foram afetadas. Esta é a primeira ocorrência de espécies do filo Cnidaria: Myxozoa em Metynnis lippincottianus.

Palavras- chave: peixe ornamental, parasitofauna, infecção.

\section{INTRODUCTION}

The high ichthyological diversity of Amazon has been a subject of study for researchers (TAVARES et al., 2018; DE ANDRADE et al., 2018; ZATTI et al., 2018; BITTENCOURT et al., 2014), but still many issues are need to be studied and understood. (MOREIRA et al., 2010). This geographic area also encompasses ecosystems that are vital for maintaining the surrounding environment, such as floodplain forests (BATISTA et al., 2015). In the state of Amapá, floodplain forests are the second largest ecosystem in the state, occupy $4.8 \%$ of the territory while the rainforest occupies approximately $70 \%$ of the state of the Amapá. Since this area is a suitable habitat for many native species (QUEIROZ et al, 
2013; PINTO, 2016), 20.83\% of these floodplain forest $(4,632.71$ hectares) are designated as the Environmental Protection Area (APA) of the Curiaú River (LIMA et al., 2013).

The APA of the Curiaú River is composed of permanent and temporary lakes within the floodplain forests, favoring a rich diversity of fish species, such as Serrasalmus rhombeus (piranha), Hoplosternum littorale (tamoatá), Cichla temensis (tucunaré), Hoplias malabaricus (traíra), and Piaractus mesopotamicus (pacu). Among these, a species of ornamental importance, Metynnis lippincottianus (Serrasalmidae) known popularly as Pratinha is widely distributed in the Brazilian basins and some French Guiana rivers. It has a diet based on vegetables, seeds, phytoplankton, mollusks and some arthropods and detritus (MOREIRA et al., 2009; HOSHINO et al., 2014).

In the Amazon, several factors influence the parasitic load of fish, such as seasonality, abiotic and biotic factors in aquatic environment water, and host ecology (NEVES et al., 2013). The diversity and ecological function of the parasites in an ecosystem can be used as tools for a better understanding of the biosphere, as well as the parasitic indexes that support parasite-host relationship analysis (TAVARES-DIAS et al. 2014 CARDOSO et al., 2018). TAKEMOTO et al. (2004) stated that all fish hosted at least one species of parasite and the location of the parasites may vary, where no organ is free from parasitism, but one organ may have more parasites than another organ.

Multiple studies have reported that gills are one of the most parasitized organs (CARDOSO et al., 2018; JERÔNIMO et al., 2014, GONÇALVES et al., 2014, VENTURA et al., 2013, SANTOS et al. 2013; OLIVEIRA et al., 2016). Gills are easily damaged by parasitic infections, being the first organ in contact with the external environment. Additionally, gills perform several functions, such as respiration, osmoregulation, and excretion. Gills are an indicator of the rate of parasitism, based on histopathological changes, such as respiratory disorders and electrolyte imbalance (FLORESLOPES et al., 2011; NASCIMENTO et al., 2012). Fish parasites may reflect the environmental quality, as well as habits of their host, considering the importance of understanding and contributing to the expansion of studies on fish parasites (FALKENBERG et al., 2019). Therefore, the present study aimed to investigate the gills of Metynnis lippincottianus from the Curiaú River basin in Macapá (eastern Amazon).

\section{MATERIALS AND METHODS}

\section{Study area}

The Curiaú river basin measures approximately $584.47 \mathrm{~km}^{2}$, almost $40 \%$ of the Curiaú River's Environmental Protection Area (APA) (LIMA et al., 2013). The Curiaú River's mouth in the Amazon River presents meandric characteristics, which may be due to the greater turbulence in the river, caused by the speed of the water current and the Amazonian river tidal regime (VASCONCELOS et al., 2011).

Specimens of $M$. lippincottianus (COPE, 1870), common fish species of the Curiaú River (Point

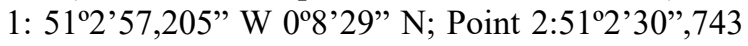
W $0{ }^{\circ} 8^{\prime} 43,087$ ' N), were collected during a 12-month period, from August 2017 to August 2018. Collections were carried out twice per month for parasitological analysis, using a $20 \mathrm{~mm}$ net between knots measuring five meters long and two meters high, being placed in points with intense activity of fishing by the local population (Figure 1).

\section{Parasites sampling procedures}

All fish were transported alive in vats containing water from the environment and artificial aeration, to the Laboratory of Morphophysiology and Animal Health (LABMORSA) at the State University of Amapá (UEAP). The specimens were desensitized through a medullary incision, using pincers and a scalpel. Then, biometric data such as total length $(\mathrm{cm})$, standard length $(\mathrm{cm})$ and weight (g) were measured.

The entire external surface, mouth, nostrils, fins, and gills were analyzed using stereoscopic binocular microscopes, to verify the existence of parasites, cysts, or lesions. During the necropsy, small gills fragments were separated between slides and coverslips, wherein foci of parasite development were identified via light microscope analysis.

Prevalence was used to analyze the infection level of the parasites following the recommendations of BUSH et al. (1997). A relative condition factor for the host was determined using body weight $(\mathrm{g})$ and total length $(\mathrm{cm})$ data following LECREN (1951) where the expected and observed weight are used to calculate, which has a value equal to one $(\mathrm{Kn}=1)$ under normal conditions.

The project was submitted to the Ethics Committee for Animal Use (CEUA), $n^{\circ}$ 012-CEUA/ CPAFAP and to the System of Authorization and Information on Biodiversity (SISBIO) $\mathrm{n}^{\circ}$ 50376-1. A license was also obtained from the Secretary of the Environment of the State of Amapá (SEMA-AP) 


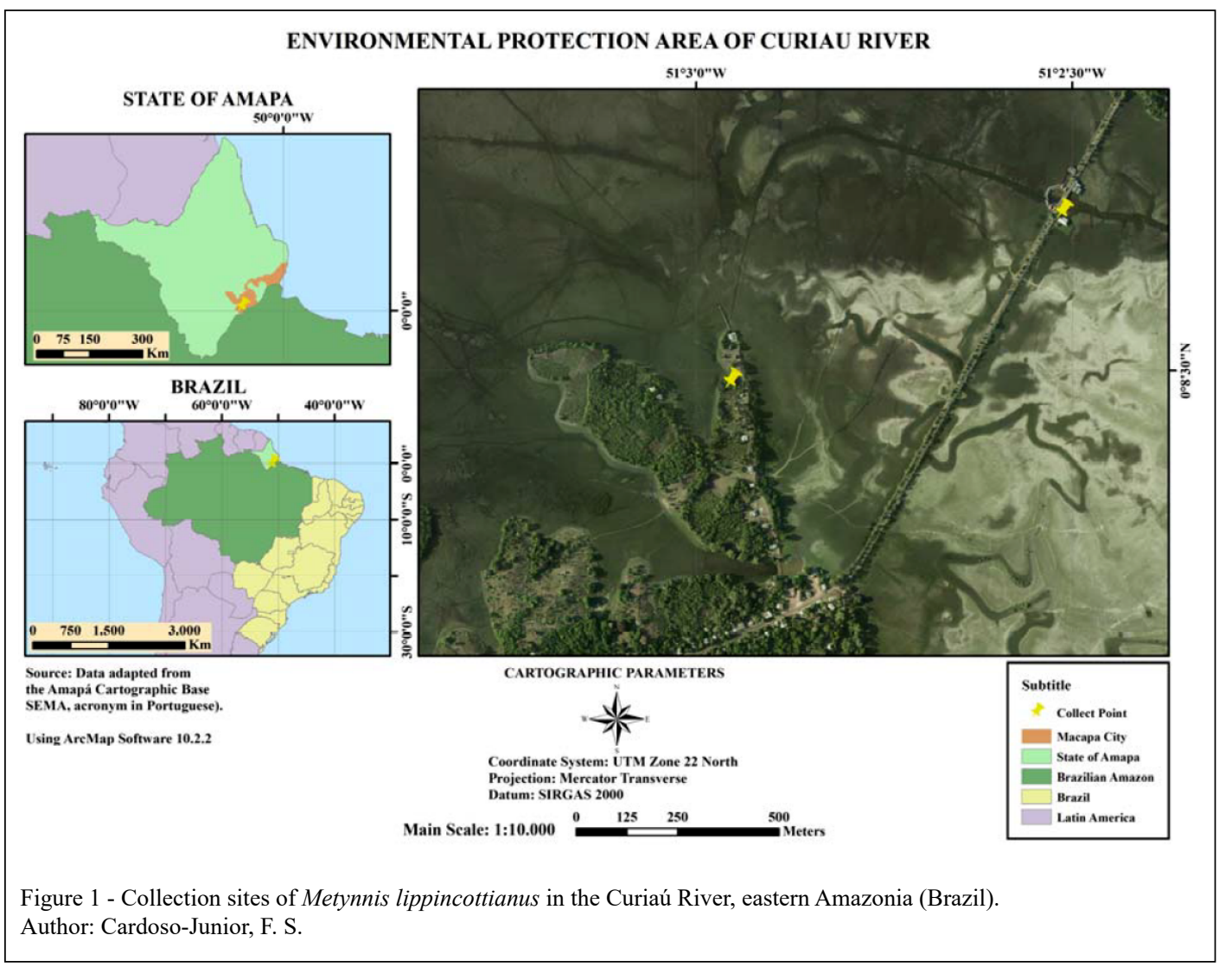

(letter $n^{\circ} 1014$ / 2016), due to the status of the research site as an Environmental Protection Area.

\section{RESULTS AND DISCUSSION}

The 200 specimens of M. lippincottianus examined from the Curiaú River, had a mean total length of $7.77 \pm 0.78 \mathrm{~cm}$; standard mean length of $6.21 \pm 0.64 \mathrm{~cm}$; and mean weight of $9.17 \pm 2.82 \mathrm{~g}$. Eighty-nine percent were parasitized by one or more species. Three taxa (Ciliophora, Cnidaria and Platyhelminthes) and 6 groups of parasites: Piscinoodinium pillulare, Trichodina sp., Henneguya sp., Myxobolus sp., monogenoids from the family Dactylogyridae, and unidentified digenetics (metacercariae) (Figure 2). Cnidarian Henneguya sp. presented the highest prevalence $(89 \%)$ among the parasites reported in gills; metacercariae showed the lowest prevalence $(15 \%)$.

The dinoflagellata Piscinoodinium pillulare was found in the gills of $44 \%$ of the analyzed $M$. lippincottianus specimens, which was lower than the prevalence reported by FLORINDO et al. (2017) in ornamental fish from Santa Catarina, which was $75 \%$ in all fish. This same parasite was reported in Cichlasoma amazonarum and in Hemibrycon surinamensis of the Igarapé of Fortaleza basin, Macapá, with a prevalence of $49 \%$ and $17.2 \%$, respectively (CARVALHO et al., 2017; HOSHINO et al. 2014; HOSHINO et al., 2014). Piscinoodinium pillulare is common in cold season of the year and is responsible for outbreaks in aquaculture, which may cause discomfort and asphyxia in hosts, as described by SANT'ANA et al (2012).

Parasitic infection of the gills in the genus Trichodina is the main cause of mortality among fish farms (MACIEL et al., 2018). In this study, the prevalence of Trichodina sp. in the gills was $19 \%$, which was higher than the prevalence $(10.4 \%)$ reported by NEVES et al. (2013) in Astronotus ocelatus from Pracuúba Lake, Amapá. Trichodina spp. was found in gills of Carnegiella strigata, Carnegiella martae, and Nannostomus eques, with a prevalence of $14.3 \%, 7.9 \%$, and $9.7 \%$, respectively; all of these fish were collected from the middle Rio Negro (TAVARES-DIAS et al., 


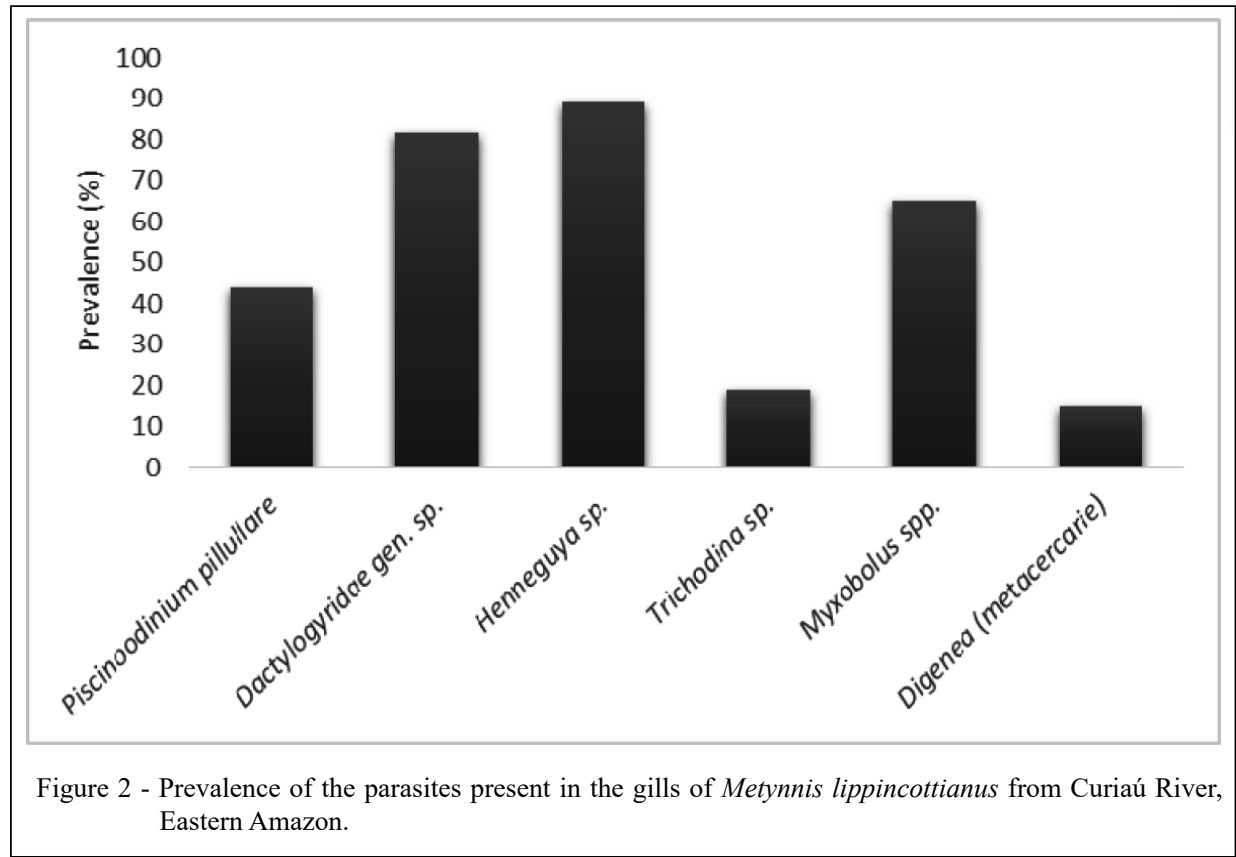

2010). Trichodina nobilis parasitized the gills in $64.3 \%$ and $84.2 \%$, respectively, of in Pterophyllum scalare and Mesonauta acora individuals (FARIAS PANTOJA et al., 2015).

In the present study, the parasite that presented the highest prevalence of infection was Henneguya sp., which infected $89 \%$ of the specimens analyzed. This prevalence was greater than thatported re in Hypophthalmus marginatus of the municipality of Cametá, in the state of Pará, in which $80 \%$ of the individuals were parasitized by Henneguya sp. (VELASCO et al., 2015), this higher prevalence can be related directly as the feeding habit of the fish species, as well as the behavioral, biological and physiological differences of these fish (ISAAC et al., 2004) because these factors can affect the structure of the parasite community (CARVALHO et al., 2017). Henneguya sp. was also described in Pimelodus maculatus, infecting 13.4\% of the gills (MARTINS et al., 2018). Henneguya paraensis was reported in $60 \%$ of the gills of Cichla temensis specimens studied (VELASCO et al., 2016). Henneguya aequidens occurred in $33.3 \%$ of the gills of Aequidens plagiozonatus individuals (VIDEIRA et al., 2015); whereas in Arapaima gigas, Henneguya arapaima parasitized the gill arches and gall bladder with a prevalence of $11.7 \%$ and $82.3 \%$, respectively (FEIJÓ et al., 2008). This parasite has high specificity for its host fish, and its parasitic action brings not only ultrastructural damages that can result in death, but also cause sterility of the host when housed in the gonads and testicles (MATOS et al., 2001).

Myxobolus spp. parasitized $65 \%$ of gills of the fish examined, a value higher than that reported in the heart of Pimelodus ornatus, from the Arari Waterfall, which had a prevalence of $13.9 \%$ in the 43 specimens analyzed (MATOS et al., 2014). LACERDA et al (2013) explained that the discrimination of the fish parasitic fauna can be based on premise that the different biogeographic regions showed a range of possibilities for the parasitic fauna structure in the host, thus explaining the differences in parasites prevalence in their hosts. A species of Myxobolus, Myxobolus maculatus, was found to parasitize $40 \%$ of the kidneys of Metynnis maculatus, a fish of the same genus as those researched in this study, collected in the Amazon River estuary (CASAL et al., 2002). Myxobolus insignis infected the gills of $66.6 \%$ of Semaprochilodus insignis (EIRAS et al., 2005) and Myxobolus sp. of 5.5\% of Colossoma macropomum (MACIEL et al., 2011), both fish species being from the Amazon basin. Myxobolus marajoensis, was found to parasitize the intestinal musculature of $20 \%$ of fish from Paracauri River, in the Island of Marajó-PA, Rhamdia quelen (ABRUNHOSA et al., 2017).

Monogenoids of the family Dactylogyridae presented the second highest prevalence, at $81.5 \%$ of 
the specimens examined. HOSHINO \& TAVARESDIAS (2014) described the presence of a species of the family Dactylogyridae in M. lippincottianus of the Igarapé Fortaleza basin / AP. The species reported was Anacanthorus jegui, with a prevalence of $95 \%$ in the 80 specimens analyzed. In another study, conducted by REVERTER et al. (2016) in gills of butterflies fishes of the Tropical Islands of the Western Pacific, parasitism by monogenea communities of the Dactylogyridae family to occurred with prevalences between $40 \%$ and $100 \%$ in the analyzed species; members of the family Dactylogyridae are thus present in both freshwater and marine environments. According to MENDOZA-FRANCO et al. (2018), the occurrence of monogenea in ornamental freshwater fish is due to the introduction of exotic fish that harbor these parasites and the pollution of the natural environment.

The presence of digenetic metacercariae larvae in the gills of $M$. lippincottianus was observed with the lowest prevalence among the parasites reported - only $15 \%$ of the individuals examined were infected. It was not possible to identify the individual species of metacercariae. In studies conducted in Lago Guaíba / RS, 13 species belonging to the phylum Platyhelminthes were parasitizing the intestines, gills, and stomach of Megaleporinus obtusidens, with prevalence between $1.66 \%$ and $86.66 \%$ in the 60 specimens analyzed (WENDT et al., 2018). There were metacercariae of Posthodiplostomum sp. parasitizing the gills of Auchenipterus nuchalis (TAVARES-DIAS, 2017) and metacercariae in the gills of $77.5 \%$ of $M$. lippincottianus (HOSHINO et al., 2014); both fish species distributed the Igarapé of Fortaleza basin. MORAIS et al., (2011) reported metacercariae of Clinostomun marginatum and Austrodiplostomum compactum, parasitizing 100\% and $15 \%$, respectively, present in Pygocentrus nattereri of central Amazon.

The relative factor of the host $(\mathrm{K} n=1.000 \pm 0.08)$ was not affected by the parasitism, since it remained very close to the standard value, that is $\mathrm{Kn}=1.0$, according LECREN (1951), thus indicating that the specimens' condition was not impacted, despite the high parasitic load. This relative condition factor indicated the well-being of the fish, thus measuring the state of animal health (VAZZOLER, 1996, LIZAMA et al., 2006). FALKENBERG et al. (2019) said that under natural conditions, fish can be infected by many species, which coexist and show interrelations, demonstrating that each host has its own community of parasites and that hosts acquire resistance, as well as adapt with the presence of parasites and thus not have a negative influence on the condition factor.

\section{CONCLUSION}

The parasitic fauna of the gills of $M$. lippincottianus comprised micro and macroparasites, was diverse in its composition, and was dominated by the phylum Cnidaria: Myxozoa. Henneguya sp. was the most prevalent parasite, while metacercariae were the least prevalent. The presence of protozoa, Trichodina sp. and Piscinoodinium pillulare, occurred in almost $50 \%$ of the specimens, and these are primarily responsible for production losses in aquaculture. The presence of two species of the genus Myxobolus was observed, which were differentiated based on spores of different shapes, since species identification for myxozoa requires molecular and ultrastructural analysis. This is first observed occurrence of species belonging to the phylum Cnidaria: Myxozoa in M. lippincottianus.

\section{DECLARATION OF CONFLICT OF INTERESTS}

The authors declare no conflict of interest. The founding sponsors had no role in the design of the study; in the collection, analyses, or interpretation of data; in the writing of the manuscript, and in the decision to publish the results.

\section{BIOETHICS AND BIOSSECURITY COMMITTEE APPROVAL}

This research was approved by the Animal Use Ethics Committee (CEUA) of EMBRAPA-AP, number 012CEUA/CPAFAP and registered in the System of Authorization and Information of Biodiversity (SISBIO), $\mathrm{n}^{\circ}$ 50376-1, as well as authorized by the Secretary of Environment of the State of Amapá (SEMA), for the reason of the study being conducted in Environmental Protection Area, under the official number $1014 / 2016$

\section{AUTHORS' CONTRIBUTIONS}

All authors contributed equally for the conception and writing of the manuscript. All authors critically revised the manuscript and approved of the final version.

\section{REFERENCES}

ABRUNHOSA, J. et al . Myxobolus marajoensis sp. n. (Myxosporea: Myxobolidae), parasite of the freshwater catfish Rhamdia quelen from the Brazilian Amazon region. Revista Brasileira de Parasitologia Veterinária, v.26, n.4, p.465-471, 2017. Available from: <http://www.scielo.br/scielo. php? script $=$ sci_arttext\&pid $=$ S1984-29612017000400465 $>$. Accessed: Aug. 14, 2018. doi: 10.1590/s1984-29612017067. 
BATISTA, A.P.B. et al. Caracterização estrutural em uma floresta de terra firme no estado do Amapá, Brasil. Pesquisa Florestal Brasileira, v.35, p.21-33, 2015. Available from: $<$ https://pfb.cnpf. embrapa.br/pfb/index.php/pfb/article/view/689>. Accessed: Feb. 20, 2018 doi: 10.4336/2015.pfb.35.81.689.

BITTENCOURT, L.S. et al. Parasites of native Cichlidae populations and invasive Oreochromis niloticus (Linnaeus, 1758) in tributary of Amazonas River (Brazil). Revista Brasileira de Parasitologia Veterinária, v.23, n.1, p.44-54, 2014. Available from: <http://www.scielo.br/scielo.php?pid=S1984$29612014000100007 \&$ script $=$ sci_arttext\&tlng $=$ es $>$. Accessed: Aug. 14, 2018. doi: 10.1590/S1984-29612014006.

BUSH, A.O. et al. Parasitology meets ecology on its own terms: Margolis et al. Revisited. The Journal of Parasitology, v.83, p.575-583, 1997. Available from: <http://parasitology.msi.ucsb. edu/sites/parasitology.msi.ucsb.edu/files/docs/publications/ parasitology\%20meets\%20ecology.pdf>. Accessed: Sep. 08, 2017. doi: $10.2307 / 3284227$.

CARDOSO, L. et al. Gill metazoan parasites of the spotted goatfish Pseudupeneus maculatus (Ostheichthyes: Mullidae) from the Coast of Pernambuco, northeastern Brazil. Brazilian. Journal of Biology, v.78, p.414-420, 2018. Availabe from: <http:/www.scielo.br/ scielo.php?script $=$ sci_arttext\&pid $=$ S1519-69842018000300414>. Accessed: Aug. 14, 2018. doi: 10.1590/1519-6984.166631.

CARVALHO, A.A.; et al. Diversity of parasites in Cichlasoma amazonarum Kullander, 1983 during rainy and dry seasons in eastern Amazon (Brazil). Journal of Applied Ichthyology, v.3, p.1178-1183, 2017. Available from: <https://www.researchgate. net/publication/319041774_Diversity_of_parasites_in Cichlasoma_amazonarum_Kullander_1983_during_rainy_and_dry_seasons_in_eastern_Amazon_Brazil $>$. Accessed: Aug. 18, 2018. doi: $1 \overline{0} .1 \overline{111} /$ jai. $1 \overline{3} 451$.

CASAL, G. et al. Ultrastructural data on the spore of Myxobolus maculatus n. sp. (phylum Myxozoa), parasite from the Amazonian fish Metynnis maculatus (Teleostei). Diseases of aquatic organisms, v.51, p.107-112, 2002. Available from: $<$ https://www. ncbi.nlm.nih.gov/pubmed/12363082>. Accessed: Mar. 18, 2018. doi: $10.3354 /$ dao051107.

DE ANDRADE, J.I.A. et al. Hematology and biochemistry of Colossoma macropomum co-infected with Aeromonas hydrophila and monogenean Anacanthorus spathulatus after treatment with seed extract of Bixa orellana. Aquaculture, v.495, p.452-457, 2018. Available from: <https:/www.sciencedirect.com/science/ article/abs/pii/S0044848618306215>. Accessed: Feb. 20, 2018. doi: 10.1016/j.aquaculture.2018.06.026.

EIRAS, J.C. et al. Métodos de estudo e técnicas laboratoriais em parasitologia de peixes. Maringá: Ed. EDUEM. 2006.

FALKENBERG, J. M. et al. Gill parasites of fish and their relation to host and environmental factors in two estuaries in northeastern Brazil. Aquatic Ecology, v.43, n.1, p.109-118, 2019. Available from: <https://www.researchgate.net/publication/331013056_Gill parasites_of_fish_and_their_relation_to_host_and_environmental_ factors_in_two_estuaries_in_northeastern_Brazil $>$. Accessed: Feb. 20, 2019. 하: $\overline{10} \cdot 1007 / \mathrm{s} 104 \overline{5} 2-019-0967 \overline{6}-6$.

FARIAS PANTOJA, W.M. et al. Parasites component community in wild population of Pterophyllum scalare Schultze, 1823 and Mesonauta acora Castelnau, 1855, cichlids from the Brazilian
Amazon. Journal of Applied Ichthyology, v.31, n.6, p.10431048. 2015. Available from: <https://www.embrapa.br/buscade-publicacoes/-/publicacao/1030674/parasites-componentcommunity-in-wild-population-of-pterophyllum-scalare-schultze1823-and-mesonauta-acora-castelnau-1855-cichlids-from-thebrazilian-amazon>. Accessed: Apr. 20, 2018. doi: 10.1111/ jai.12903.

FEIJÓ, M. M. et al. Light and scanning electron microscopy of Henneguya arapaima n. sp. (Myxozoa: Myxobolidae) and histology of infected sites in pirarucu (Arapaima gigas: Pisces: Arapaimidae) from the Araguaia River, Brazil. Veterinary Parasitology, v.157, n.2, p.59-64, 2008. Available from: <https:// www.ncbi.nlm.nih.gov/pubmed/18771855>. Accessed: Apr. 28, 2018. doi: 10.1016/j.vetpar.2008.06.009.

FLORES-LOPES, F; et al. Histopathologic alterations observed in fish gills as a tool in environmental monitoring. Brazilian Journal of Biology, v.71, n.1, p.179-188 2011. Available from: <http://www.scielo.br/scielo.php?script=sci_ arttext\&pid=S1519-69842011000100026>. Accessed: May, 01, 2018. doi: 10.1590/S1519-69842011000100026.

FLORINDO, M.C. et al. Protozoan parasites of freshwater ornamental fish. Latin American. Journal of Aquatic Research, v.45, p.948-956, 2017. Available from: <https://scielo.conicyt.cl/ pdf/lajar/v45n5/0718-560X-lajar-45-05-0948.pdf > . Accessed: Oct. 03, 2018. doi: 10.3856/vol45-issue5-fulltext-10.

HOSHINO, M.D.F.G. et al.. First study on parasites of Hemibrycon surinamensis (Characidae), a host from the Eastern Amazon region. Revista Brasileira de Parasitologia Veterinária, v.23, p.343-347, 2014. Available from: <https:/www.ncbi.nlm.nih.gov/ pubmed/25271454> . Accessed: May, 01, 2018. doi: 0.1590/S198429612014069 .

HOSHINO, M.D.F.G.; et al. Ecology of parasites of Metynnis lippincottianus (Characiformes: Serrasalmidae) from the eastern Amazon region, Macapá, State of Amapá, Brazil. Acta Scientiarum. Biological Sciences, v.36, p.249-255. Available from: <https://www.embrapa.br/amapa/busca-de-publicacoes/-/ publicacao/1009555/ecology-of-parasites-of-metynnislippincottianus-characiformes-serrasalmidae-from-the-easternamazon-region-macapa-state-of-amapa-brazil>. Accessed: Jun. 04, 2018. doi: 10.4025/actascibiolsci.v36i2.19876.

ISAAC, A. et al. Composição e estrutura das infracomunidades endoparasitárias de Gymnotus spp. (Pisces: Gymnotidae) do rio Baía, Mato Grosso do Sul, Brasil. Acta Scientiarum. Biological Sciences, v.26, n.4, p.453-462, 2004. Available fom: <https:// www.researchgate.net/publication/247915423_Composicao_e_ estrutura_das_infracomunidades_endoparasitarias_de Gymnotus_spp_Pisces_Gymnotidae_do_rio_Baia_Mato_Grosso_do_Sul_Brasil $>$. Accessed: Feb. $20, \overline{2019}$. doi: $\overline{10.4025 /}$ actascibiolsci.v2 6 i4.1527.

JERÔNIMO, G. et al. Haematological and histopathological analysis in South American fish Piaractus mesopotamicus parasitized by monogenean (Dactylogyridae). Brazilian Journal of Biology, v.74, n.4, p.1000-1006, 2014. Available from: <http://www.scielo.br/ scielo.php?script=sci_arttext\&pid=S1519-69842014000401000>. Accessed: Jun. 04, 201̄8. doi: 10.1590/1519-6984.09513.

LACERDA, A. C. F. et al. Peixes introduzidos e seus parasitos. In: PAVANELLI, G. et al. Parasitologia de peixes de água doce do Brasil. Maringá: Eduern, 2013. pp.169-193. 
LECREN, E. D. The length-weight relationship and seazonal cycle in gonad weight and condition in the perch (Perca fluviatilis). Journal of Animal Ecology, v.20, n.2, p.201-219, 1951.

LIMA, R.B. et al. Caracterização agroecológica e socioeconômica dos moradores da comunidade quilombola do Curiaú, Macapá-AP, Brasil. Biota Amazônia, v.3, n.113-138 2013. Available from: $<$ https://periodicos.unifap.br/index.php/biota/article/view/861 $>$. Accessed: Feb. 18, 2018. doi: 10.18561/2179-5746/biotaamazonia. v3n3p113-138.

LIZAMA, M.A. P.; et al. Influence of the seasonal and environmental patterns and host reproduction on the metazoan parasites of Prochilodus lineatus (Valenciennes, 1836) (Prochilodontidae) of the Upper Parana' River floodplain, Brazil. Brazilian Archives of Biology and Technology, v.49, n.4, p.611-622, 2006.

MACIEL, P.O. et al. Myxobolus sp. (Myxozoa) no sangue circulante de Colossoma macropomum (Osteichthyes, Characidae). Revista Brasileira de Parasitologia Veterinária, v.20, n.1, p.82-84, 2011. Available from: <http://www.scielo.br/scielo.php?script=sci_artte xt\&pid=S1984-29612011000100018>. Accessed: Sep. 20, 2018. doi: 10.1590/S1984-29612011000100018.

MACIEL, P.O. et al. Trichodinidae in commercial fish in South America. Reviews in Fish Biology and Fisheries, v.28, p.35-56, 2018. Available from: <https://link.springer.com/article/10.1007/ s11160-017-9490-1>. Accessed: Sep. 20, 2018. doi: 10.1007/ s11160-017-9490-1.

MARTINS, M. et al. Henneguya sp. (Myxozoa: Myxobolidae) em Pimelodus maculatus (Osteichthyes: Siluridae) do Reservatório de Volta Grande, Minas Gerais, Brasil. Boletim do Instituto de Pesca, v.30, n.1, p.01-07, 2018. Available from: <https://www. pesca.sp.gov.br/boletim/index.php/bip/article/view/Martins30_1>. Accessed: Oct. 15, 2018

MATOS, E. et al. Incidência de parasitas do Phylum Myxozoa (Sub-reino Protozoa) em peixes da região amazônica, com especial destaque para o gênero Henneguya. Revista de Ciência Agrária, v.36, p.83-99, 2001. Available from: < https://periodicos.ufra.edu. br/index.php/ajaes/article/view/1996>. Accessed: Mar. 20, 2018.

MATOS, E. et al. Infection of the heart of Pimelodus ornatus (Teleostei, Pimelodidae), by Myxobolus sp. (Myxozoa, Myxobolidae). Revista Brasileira de Parasitologia Veterinária, v.23, p.543-546, 2014. Available from: <http://www.scielo.br/ scielo.php?script=sci arttext\&pid=S1984-29612014000400543>. Accessed: Mar. 20, 2018. doi: 10.1590/S1984-29612014083.

MENDOZA-FRANCO,E.F.etal.Ecto-andendo-parasitic monogeneans (Platyhelminthes) on cultured freshwater exotic fish species in the state of Morelos, South-Central Mexico. ZooKeys, v.776, p.1-12, 2018. Available from: $<$ https://zookeys.pensoft.net/article/26149/>. Accessed: Mar. 21, 2018. doi: 10.3897/zookeys.776.26149.

MORAIS, A. M. et al. Clinostomum marginatum (Braun, 1899) and Austrodiplostomum compactum (lutz, 1928) metacercariae with zoonotic potencial on Pygocentrus nattereri (Kner, 1858) (Characiformes: Serrasalmidae) from Central Amazon, Brazil. Neotropical Helminthology, v.5, n.1, p.8-15, 2011. Available from: $<$ https://www.arca.fiocruz.br/handle/icict/16850 $>$. Accessed: Nov. 16, 2018. doi: 10.1645/15-773.

MOREIRA, L.H.A. et al. Ecological aspects of metazoan endoparasites of Metynnis lippincottianus (Cope, 1870)
(Characidae) from Upper Paraná River floodplain, Brazil. Helminthologia, v.46, p.214-219, 2009. Available from: $<$ https://www.researchgate.net/publication/225331558_ Ecological aspects of metazoan_endoparasites of Metynnis lippincottianus_Cope_1870_Characidae_from_Upper_Parana River_floodplain_Brazil $>$. Accessed: Mar. 10, 2018. doi: $10.2478 /$ s11687-009-0040-9.

MOREIRA, L.H.D.A. et al. The influence of parasitism on the relative condition factor $(\mathrm{Kn})$ of Metynnis lippincottianus (Characidae) from two aquatic environments: the upper Parana river floodplain and Corvo and Guairacá rivers, Brazil. Acta Scientiarum. Biological Sciences, v.32, p.83-86, 2010. Available from: <http://periodicos.uem.br/ojs/index.php/ActaSciBiolSci/ article/view/3668>. Accessed: Mar. 10, 2018. doi: 10.4025/ actascibiolsci.v32i1.3668.

NASCIMENTO, A.A. et al. Fish gills alterations as potential biomarkers of environmental quality in a eutrophized tropical river in south-eastern Brazil. Journal of Veterinary Medicine Series C: Anatomia Histologia Embryologia, v.41, n.3, p.209-216, 2012. Available from: $<$ https://onlinelibrary.wiley.com/doi/abs/10 $.1111 / \mathrm{j} .1439-0264.2011 .01125 . \mathrm{x}>$. Accessed: Mar. 12, 2018 doi: 10.1111/j.1439-0264.2011.01125.x.

OLIVEIRA, M.S.B.; et al. Communities of parasite metazoans in Piaractus brachypomus (Pisces, Serrasalmidae) in the lower Amazon River (Brazil). Brazilian Journal of Veterinary Parasitology, v.25, n.2, p.151-157, 2016. Available from: <http:// www.scielo.br/scielo.php?script $=$ sci_abstract\&pid $=$ S 198429612016000200151\&lng=pt\&nrm=iso\&tlng=en>. Accessed: May, 25, 2018. doi: 10.1590/S1984-29612016022.

NEVES, L.R. et al. Seasonal influence on the parasite fauna of a wild population of Astronotus ocellatus (Perciformes: Cichlidae) from the Brazilian Amazon. The Journal of Parasitology, v.99, p.718-721, 2013. Available from: <https://www.ncbi.nlm.nih.gov/ pubmed/23421456>. Accessed: May, 28, 2018. doi: 10.1645/12-84.1.

PINTO, M.J.S. Conhecendo o Amapá. Belém: Cultural Brasil, 2016.

QUEIROZ, L.J. et al. Peixes do Rio Madeira. São Paulo: Santo Antônio 3 Energia, 2013.

REVERTER, M. et al. Gill monogenean communities (Platyhelminthes, Monogenea, Dactylogyridae) of butterflyfishes from tropical Indo-West Pacific Islands. Parasitology, v.143, p.1580-1591, 2016. Available from: <https:/www.ncbi.nlm.nih. gov/pubmed/27573880>. Accessed: Oct. 16, 2018. doi: 10.1017/ S0031182016001463.

SANT'ANA, F.J. et al. Surtos de infecção por Piscinoodinium pillulare e Henneguya spp. em pacus (Piaractus mesopotamicus) criados intensivamente no Sudoeste de Goiás. Pesquisa Veterinária Brasileira, v.3, p.121-125, 2012. Available from: <http://www. scielo.br/scielo.php?pid=S0100-736X2012000200005\&script $=$ sci abstract\&tlng $=\mathrm{pt}>$. Accessed: May, 30, 2018. doi: 10.1590/S0100736X2012000200005.

SANTOS, E.F. et al. Fauna parasitária de tambaqui Colossoma macropomum (Characidae) cultivado em tanque-rede no estado do Amapá, Amazônia oriental, Acta Amazonica v.43, n.1, p.105-112, 2013. Available from: <http://www.scielo. br/scielo.php?pid=S0044-59672013000100013\&script $=$ sci abstract\&tlng=pt $>$. Accessed: Mar. 15, 2018. doi: 10.1590/S004459672013000100013. 
TAKEMOTO, R.M. et al. Parasitos de águas continentais IN: RANZANI-PAIVA, M.J.T. et al. Sanidade de organismos aquáticos. São Paulo: Livraria Varela, 2004, p. 179-198.

TAVARES-DIAS, M. etal.Parasitic fauna of eight species of ornamental freshwater fish species from the middle Negro River in the Brazilian Amazon Region. Revista Brasileira de Parasitologia Veterinária, v.19, n.2, p.29-33, 2010. Available from: <http://www.scielo.br/ scielo.php?script $=$ sci arttext\&pid $=$ S1984-29612010000200007 $>$. Accessed: Mar. 15, 201̄8. doi: 10.4322/rbpv.01902007.

TAVARES-DIAS, M. et al. Ecology and seasonal variation of parasites in wild Aequidens tetramerus, a Cichlidae from the Amazon. Acta Parasitologica, v.54, n.1, p.158-164, 2014. Available from: <https:// www.ncbi.nlm.nih.gov/pubmed/24570063>. Accessed: May, 17, 2018. doi: 10.2478/s11686-014-0225-3.

TAVARES-DIAS, M. Community of protozoans and metazoans parasitizing Auchenipterus nuchalis (Auchenipteridae), a catfish from the Brazilian Amazon. Acta Scientiarum. Biological Sciences, v.39, n.1, p.123-128, 2017. Available from: <http:// periodicos.uem.br/ojs/index.php/ActaSciBiolSci/article/ view/32836>. Accessed: Sep. 19, 2018. doi: 10.4025/actascibiolsci. v39i1.32836.

TAVARES, G.C. et al. Disease outbreaks in farmed Amazon catfish (Leiarius marmoratus x Pseudoplatystoma corruscans) caused by Streptococcus agalactiae, $S$. iniae, and $S$. dysgalactiae. Aquaculture, v.495, p.384-392, 2018. Available from: <https://www.sciencedirect.com/science/article/abs/pii/ S0044848618308196>. Accessed: May, 09, 2018. doi: 0.1016/j. aquaculture.2018.06.027.

VASCONCELOS, H.C.G.; et al. Alimentação de Potamotrygon motoro (Chondrichthyes, Potamotrygonidae) na planície de inundação da APA do Rio Curiaú, Macapá-Amapá-Brasil. Biota Amazônia, v.1, n.2, p.66-73, 2011. Available from: $<$ https://periodicos.unifap.br/index.php/biota/article/view/362>. Accessed: Oct. 20, 2018. doi: 10.18561/2179-5746/biotaamazonia. v1.n2.p66-73.

VAZZOLER, A. E. A. M Biologia e reprodução de peixes teleósteos: teoria e prática. Maringá: Ed. EDUEM. 1996.
VELASCO, M. et al. Infection by Henneguya sp. (Myxozoa) in the bone tissue of the gill filaments of the Amazonian catfish Hypophthalmus marginatus (Siluriformes). Revista Brasileira de Parasitologia Veterinária, v.24, p.365-369, 2015. Available from: <http://www.scielo.br/scielo.php?script=sci_arttext\&pid $=$ S1984-29612015000300365>. Accessed: Sep. 20, 2018. doi: 10.1590/S1984-29612015021.

VELASCO, M et al. Henneguya paraensis n. sp. (Myxozoa; Myxosporea), a new gill parasite of the Amazonian fish Cichla temensis (Teleostei: Cichlidae): morphological and molecular aspects. Parasitology Research, v.115, n.5, p.1779-1787, 2016. Available from: < https://www.ncbi.nlm.nih.gov/pubmed/26847632>. Accessed: Sep. 20, 2018. doi: 10.1007/s00436-016-4916-6.

VENTURA, A.S. et al. Fauna parasitária dos híbridos siluriformes cachapinta e jundiara nos primeiros estágios de desenvolvimento. Pesquisa Agropecuária Brasileira, v.48, n.8, p.943-949, 2013. Available from: $<$ https://seer.sct.embrapa.br/index.php/pab/article/ view/11388>. Accessed: Oct. 18, 2018. doi: 10.1590/S0100204X2013000800019.

VIDEIRA, M. et al. Morphological aspects of Henneguya aequidens n. sp. (Myxozoa: Myxobolidae) in Aequidens plagiozonatus Kullander, 1984 (Teleostei: Cichlidae) in the Amazon region, Brazil. Parasitology Research, v.114, n.3, p.1159-1162, 2015. Available from: <http://www.bioone.org/doi/abs/10.1645/15-773>. Accessed: Mar. 20, 2018. doi: 0.1007/s00436-014-4295-9.

WENDT, E. W. et al. Helminth fauna of Megaleporinus obtusidens (Characiformes: Anostomidae) from Lake Guaíba: analysis of the parasite community. Parasitology research, v.117, p.2445-256, 2018. Available from: <https://www.ncbi.nlm.nih.gov/pubmed/29858940>. Accessed: Sep. 14, 2018. doi: 10.1007/s00436-018-5933-4.

ZATTI, S.A.etal.Ceratomyxagracilliman.sp.(Cnidaria: Myxosporea) provides evidence of panmixia and ceratomyxid radiation in the Amazon basin. Parasitology, v.145, n.9, p.1-10, 2018. Available from: <https://www.cambridge.org/core/journals/parasitology/ article/ceratomyxa-gracillima-n-sp-cnidaria-myxosporea-providesevidence-of-panmixia-and-ceratomyxid-radiation-in-the-amazonbasin/885CF2EB831DB1BB09B0506D90FA5346>. Accessed: Nov. 16, 2018. doi: 10.1017/S0031182017002323. 